Research article

\title{
Wetness index based on landscape position and topography (WILT): Modifying TWI to reflect landscape position
}

\author{
Menberu B. Meles ${ }^{\text {a,b, }}$, Seth E. Younger ${ }^{a}$, C. Rhett Jackson ${ }^{a}$, Enhao Du ${ }^{c}$, Damion Drover ${ }^{\mathrm{d}}$ \\ ${ }^{a}$ Warnell School of Forestry and Natural Resources, Univ. of Georgia, Athens, GA, 30605, USA \\ ${ }^{\mathrm{b}}$ USDA-ARS Southwest Watershed Research Center, Tucson, AZ, 85719, USA

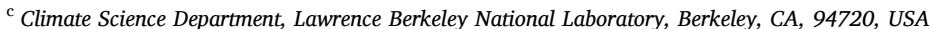 \\ d Departmnet of Forest Resources and Environmental Conservation, Virginia Tech, Blacksburg, VA, 24061, USA
}

\section{A R T I C L E I N F O}

\section{Keywords:}

WILT

Topographic wetness index

Relative landscape position

Depth to groundwater

Hydric soil

\begin{abstract}
A B S T R A C T
Water and land resource management planning benefits greatly from accurate prediction and understanding of the spatial distribution of wetness. The topographic wetness index (TWI) was conceived to predict relative surface wetness, and thus hydrologic responsiveness, across a watershed based on the assumption that shallow slope-parallel flow is a major driver of the movement and distribution of soil water. The index has been extensively used in modeling of landscape characteristics responsive to wetness, and some studies have shown the TWI performs well in landscapes where interflow is a dominant process. However, groundwater flow dominates the hydrology of low-slope landscapes with high subsurface conductivities, and the TWI assumptions are not likely to perform well in such environments. For groundwater dominated systems, we propose a hybrid wetness index (Wetness Index based on Landscape position and Topography, WILT) that inversely weights the upslope contributing area by the distance to the nearest surface water feature and the depth to groundwater. When explicit depth to groundwater data are not available, height above and separation from surface water features can act as surrogates for proximity to groundwater. The resulting WILT map provides a more realistic spatial distribution of relative wetness across a low-slope Coastal Plain landscape as demonstrated by improved prediction of hydric soils, depth to groundwater, nitrogen and carbon concentrations in the A horizon of the soil profile, and sensitivity to DEM scale.
\end{abstract}

\section{Introduction}

Accurately characterizing the spatial distribution and extent of wetness across landscapes has paramount importance in land and water resource management and conservation practices. The topographic wetness index (TWI) has been used as an estimator of relative wetness assuming that a large fraction of hillslope flow occurs as slope-parallel lateral flow such that flow accumulation should increase with local contributing area and decrease with local slope. It is defined as TWI $\ln s c a / \tan \beta$, where $s c a$ is the specific contributing area (upslope contributing area per unit contour length) draining to each grid cell and $\tan \beta$ is the local slope. TWIs represent the propensity of subsurface flow to accumulate in a grid cell and thus increase soil moisture and the frequency of saturated conditions (e.g. Moore et al., 1993). This concept has worked well where the subsurface flow assumptions are valid, i.e. in mountainous terrain and areas where shallow interflow dominates the flow components and the surface runoff contributing areas are limited to small saturated areas at the bottom of hillslopes. It was initially introduced to define an index of hydrological similarity on a catchment scale (Kirkby and Weyman, 1974; Kirkby, 1975; Kirby, 1978) and was later integrated with soil transitivity at saturation (Beven, 1986) to become a hydrological modeling concept that lead to the development of the widely used TOPMODEL. TWI has also been used in global scale land surface modeling and estimation of wetland areas (Marthews et al., 2014), in spatial mapping of soil moisture structures (e.g. Higginbottom et al., 2018; Western et al., 1999), tree growth modeling (e.g, Mohamedou, et al., 2019), predicting soil attributes like organic matter content, denitrification processes, extractable $\mathrm{P}, \mathrm{PH}$, silt and sand content, to define flow paths in geochemical modeling (e.g. Li et al., 2018a; Moore et al., 1993; Robson et al., 1992), predicting spatial patterns and richness of plant species (e.g, Sørensen et al., 2006; Zinko et al., 2005; Zinko, 2004; Moore et al., 1993), mapping forested wetlands, flowpath

\footnotetext{
* Corresponding author. USDA-ARS Southwest Watershed Research Center, Tucson, AZ, 85719, USA.

E-mail address: menberu.bitew@usda.gov (M.B. Meles).
} 


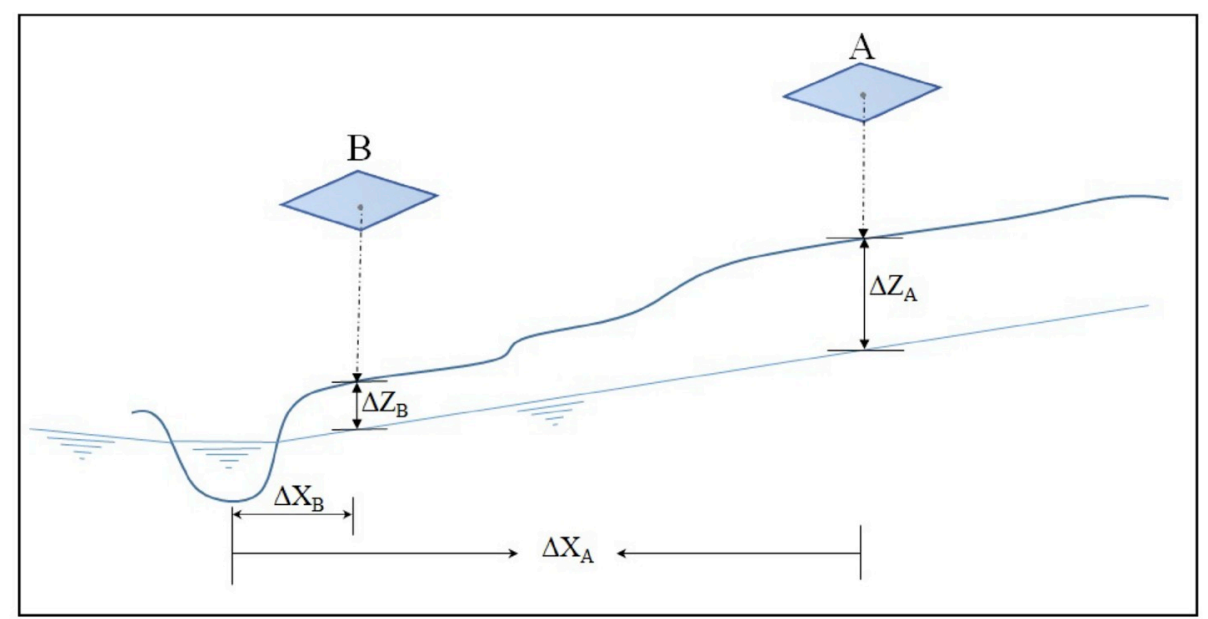

Fig. 1. Conceptual model showing TWI modification parameters ( $\Delta \mathrm{X}$ and $\Delta \mathrm{Z}$ ) calculated from a DEM and used to create WILT. $\Delta \mathrm{X}$ is the distance of a cell from the nearest water cell and $\Delta \mathrm{Z}$ shows the depth-to-groundwater.

patterns, and hydrologic connectivity (Jancewicz et al., 2019; Li et al., 2018b; Epting et al., 2018; Lang et al., 2013), and determining placement of vegetative buffers for agricultural watersheds (e.g. Wallace et al., 2018; Dosskey and Qiu, 2011; Dosskey et al., 2013).

Tweaks to the TWI framework have been common as investigators have found issues with aspects of landscape characterization using the index. Ali et al. (2013) evaluated the ability of various wetness indices to predict field observed connected saturated areas in the $30 \mathrm{~km}^{2}$ Grinock watershed in Scotland. Compared to other geomorphic indices, TWI showed better prediction of observed saturated areas, but the matches were mainly restricted to permanent stream channel sections. Other studies showed that TWIs explain only portions of measured variables like saturated areas (Guntner et al., 2004), soil pH, groundwater level, and soil moisture (Sorensen et al., 2006). TWI has been used in watershed modeling to predict spatially variable quick flow (e.g. Beven and Kirkby, 1979; Woods and Sivapalan, 1997; Woods et al., 1995), but it lacks the ability to represent outcropped water and shallow groundwater intersecting valley edges. Previous researchers have modified TWI using saturated hydraulic conductivity and soil depth as indicators of soil storage capacity (Walter et al., 2002). Ma et al. (2010) incorporated topographic aspects and terrain position as weighting factors to revise the TWI model for improved representation of soil moisture content. Based on the weakness observed in the ability of TWIs to model spatial patterns of soil moisture and drainage conditions (e.g. Guntner et al., 2004; Iverson et al., 2004; Case et al., 2005), Murphy et al. (2009, 2011) created a topography-based depth-to-water (DTW) index that represents the elevation difference between a surface and the nearest open water feature as a summation of slope along least slope path.

TWI assumptions render the index less useful for predicting relative wetness in landscapes where interflow is a minor component of hillslope flow. In the Upper Coastal Plain of the southeastern U.S, slopes are gentle, and low conductivity horizons that would generally enable interflow are relatively leaky, allowing vertical percolation to groundwater rather than interflow moving laterally to valleys (Jackson et al., 2014). Previous application of TWI on the rolling, highly permeable terrain of the Savannah River Site in the Upper Coastal Plain in South Carolina (SC) indicated that TWI wetness was inconsistent with field observations of factors related to wetness (Drover et al., 2015), and the spatial distribution of TWI was highly sensitive to Digital Elevation Model (DEM) resolution. The two important limitations in the relative wetness maps predicted at this site by TWIs were as follows. First, high TWI values extended to the ridge top where relative wetness is low. This limitation is attributed to the logarithmic scale operation of the TWI model, which minimizes the difference in wetness values between grid cells when there is large difference in the ratio of contributing area to slope. Second, high variability of TWI values occurred in the riparian valleys where little variability in wetness is observed in the field. This is partially attributed to a "bumpy" valley topography creating high contrasts between neighboring DEM cells. In general, wetness is much less variable at small scale than predicted by TWI in this landscape.

The main objectives of this work were to develop a topographic based index that accurately characterizes the spatial structure of wetness that can help guide environmental management actions. Hence, we present a modified wetness index which incorporates the depth to groundwater and the horizontal distance from each pixel to surface water to create spatial patterns of wetness that are more consistent with field observations in our study region. We modified the TWI to better predict relative wetness in catchments where groundwater is the dominant flow path and interflow occurs but is less important. In such landscapes, surface water features (streams, wetlands, ponds, and lakes) mark relatively continuous positions of the water table, i.e. groundwater outcrop locations. Observations of such landscape reveal the obvious and simple conclusion that soils are generally wetter near the streams and lower in the landscape, but that topographic convergence is still important. As a result, we modified TWI by incorporating the position of each grid cell relative to the nearest surface water features. The closer the area is to a stream/lake, the wetter the area is and vice versa. For example, Cell A in Fig. 1 is relatively dry not only because of the small surficial contributing area but also because it is high in the landscape where vertical infiltration is more dominant (e.g. Du et al., 2016; Jackson et al., 2014; Jackson et al., 2016). Cell B, being situated downslope, has a larger upslope contributing area but its wetness is also affected by the position of the regional water table. Cells neighboring cell B with little upslope contributing area can be very wet due to proximity to groundwater and thus feature hydrologic behavior similar to cells with a large surficial contributing area.

Specifically, we assume that wetness is inversely proportional to $\Delta \mathrm{X}$ and $\Delta \mathrm{Z}$ in a groundwater-dominated landscape, where $\Delta \mathrm{Z}$ is the depth to groundwater and $\Delta \mathrm{X}$ is the horizontal distance from the nearest surface water feature (Fig. 1). We modify TWI by dividing the upslope contributing area $A$ by $\Delta \mathrm{X}$ and $\Delta \mathrm{Z}$ as follows:

WILT $\ln \frac{A}{\Delta \mathrm{X} \quad \Delta \mathrm{Z} \tan \beta}$

In WILT, we can conceptualize the dimensionless ratio of the surface contributing area to valley separation index (SCAVSI) as the upslope contributing area divided by-products of the distance to wet cells $(\Delta \mathrm{X})$ and depth-to-groundwater level $(\Delta \mathrm{Z})$. The effect of this modification is to suppress high index values high in the landscape and reduce index variability low in the landscape. 

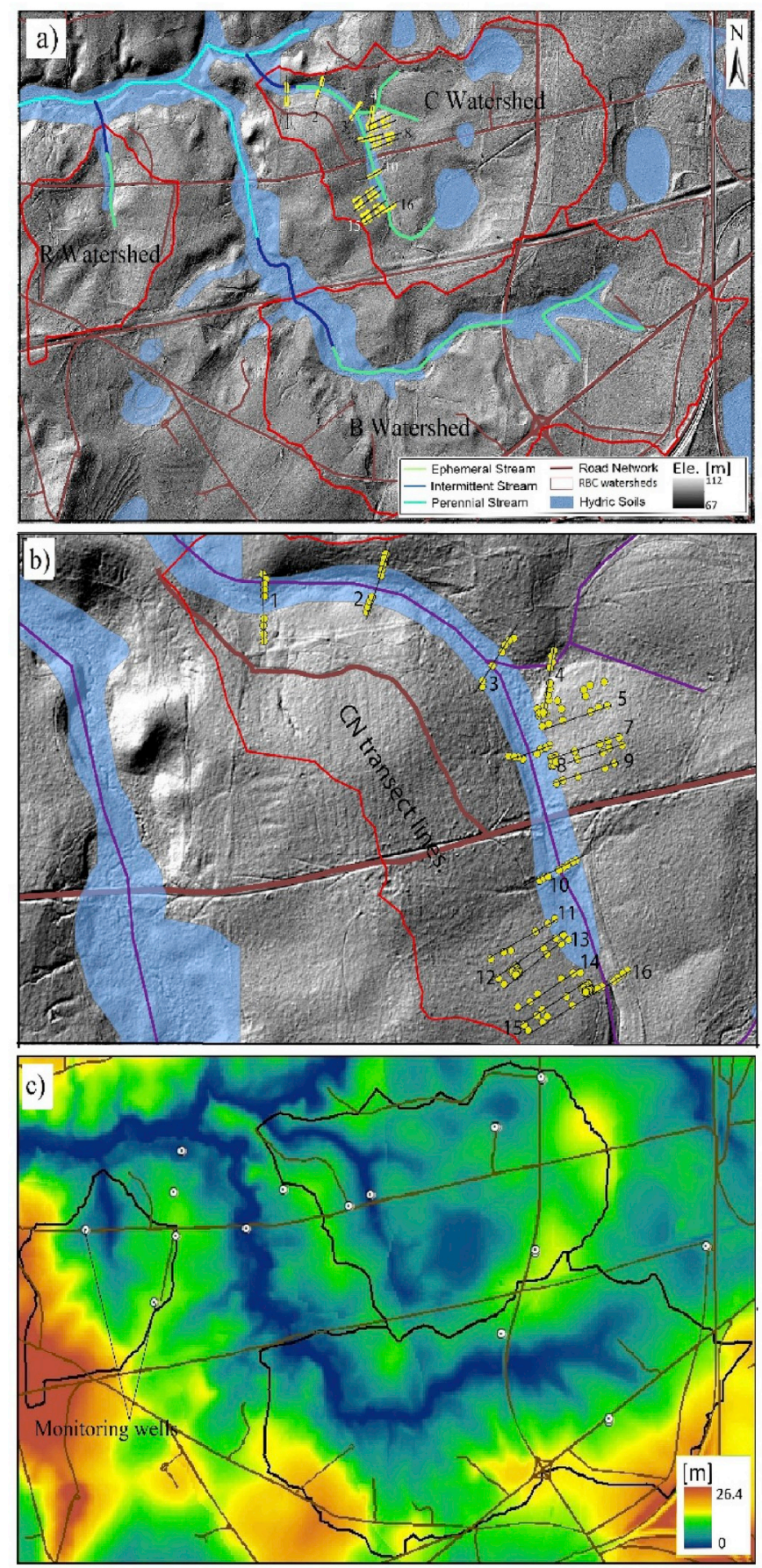

Fig. 2. a) Map of the study site showing perennial, intermittent and ephemeral stream reaches in RBC watersheds and location of hydric soil cover, b) $10 \mathrm{~m}$ resolution map of average observed depth-to-groundwater table based on monthly observations of monitoring boreholes and riparian piezometers in Fourmile Branch, c) soil sample locations along the 16 transects, and d) LiDAR based LAI estimation for the study site.

Here we apply both TWI and WILT to a first order, low slope, Coastal Plain watershed where vertical infiltration and groundwater outcropping to streams are the dominant hydrologic processes, but where some interflow occurs over an argillic Bt horizon (Du et al., 2016; Jackson et al., 2014). The relative performances of the two indices in this landscape were evaluated based on spatial correspondence with maps of hydric soils, depth-to-groundwater, and distributional characteristics of index values within valley grid cells. Furthermore, the spatial distribution of soil carbon (C) and nitrogen $(\mathrm{N})$ content along numerous transects were used to evaluate the performances of the wetness indices to explain soil quality variables affected by wetness. The two indices were also compared with respect to their sensitivity to DEM resolution.

\section{Study site}

TWI and WILT were applied in upper Fourmile Branch of the U.S. Department of Energy (DOE) Savannah River Site (SRS) in South Carolina, USA. Upper Fourmile Branch contains three first-order watersheds, R, B and C, that are perennial in wet years and intermittent in dry years and that drain to the perennially flowing main stem (Fig. 2a). The hydrology and water quality of these watersheds has been extensively monitored since 2007 (Du et al., 2016; Klaus et al., 2015; Griffiths et al., 2016, 2017). Most of the hillslopes are gently sloping in the $2-5 \%$ range with maximum slopes of $25-30 \%$ mostly along valley margins. The surface soils are sandy to sandy loam in texture consisting of $80-90 \%$ sand. Clay content increases with depth to $35 \%$ or more in the underlying argillic sandy clay loam $B_{t}$ horizon (Kilgo and Blake, 2005). The riparian zones, Carolina bays and well-drained depressions are dominated by hydric soils (Fig. 2a). The landcover consists of managed loblolly pines in the uplands and unmanaged mixed hard wood forest or scrub shrubs in the riparian zones.

Infiltration rates are high, and while perching and some interflow occur over the argillic $B_{t}$ horizon (Du et al., 2016), high leakage rates through the $B_{t}$ horizon (Jackson et al., 2016) render groundwater flow the dominant hydrologic process (Jackson et al., 2014; Klaus et al., 2015). Streamflow and groundwater interactions are characterized by a surficial aquifer that flows through thick and highly conductive sedimentary formation of the coastal plain consisting of alternating sand, some limestone and intermittent clay layers (e.g. Aadland et al., 1995). The water table in upper Fourmile is extensively monitored by networks of wells and riparian piezometers distributed across R, B, and C watersheds. Depths to groundwater range from $<1 \mathrm{~m}$ in the valleys and wetlands to $24 \mathrm{~m}$ near the watershed divides.

\section{Data and methods}

\subsection{DEM analysis and WILT calculation}

The study utilized a LiDAR based DEM obtained over the entire SRS in May 2009. The LiDAR data has a horizontal accuracy of $0.5 \mathrm{~m}$ and a vertical accuracy of $\quad 0.15 \mathrm{~m}$ in open flat areas or $0.5 \mathrm{~m}$ in forested areas. A $1 \mathrm{~m}$ bare-ground DEM was created using the FUSION 3.4 GroundFilter program. We re-sampled the $1 \mathrm{~m} \mathrm{DEM}$ to $2 \mathrm{~m}, 5 \mathrm{~m}, 10 \mathrm{~m}$, $20 \mathrm{~m}, 30 \mathrm{~m}$, and $50 \mathrm{~m}$ resolutions. To illustrate the variation in representativeness of both indexes, maps of both were compared at the $10 \mathrm{~m}$ resolution (Fig. 3a and b). We evaluated the effect of DEM resolution on wetness structure and pattern using the resampled resolutions. Several researchers have looked at the effect of DEM resolution on distribution of TWIs (Quinn et al., 1991; Sorensen and Seibert, 2007; Kienzle, 2004; Drover et al., 2015). Different DEM resolutions result in different spatial patterns of TWI, as DEM resolution affects the calculation of slopes. We used a 10 m DEM, based on existing research (Quinn et al., 1991 and Drover et al., 2015). The $10 \mathrm{~m}$ resolution is coarse enough to be relatively unaffected by human modifications such as roads and ditches, which affect the flow accumulation algorithm, but is not coarse enough to remove local topographic variability. Stream networks and other surface water cells were generated using the ArcHydro terrain analysis tool (Maidment, 2002) and maximum extents were verified using ground truthed data for upper Fourmile Branch.

Specific contributing area, slope, distance to water body cells, and depth-to-groundwater were obtained from GIS analysis. Water body cells including streams, lakes, and ponds were identified using terrain analysis tools in a GIS. Verification of the spatial extents of the stream reaches and water bodies was based on quadrangle maps, aerial photographs, and field observations of the watershed, which are commonly 
Table 1

Classification of calculated TWI and WILT values into five classes based on the percentile rank of the wetness values. The first $10 \%$ is considered as very dry, then $15 \%, 40 \%, 15 \%$ as dry TWI, medium and wet wetness class values respectively and the last $20 \%$ was considered as very wet wetness.

\begin{tabular}{lll}
\hline TWI Classes & TWI & WILT \\
\hline 1. Very Wet & $>19.8$ & $>22.2$ \\
2. Wet & 19.8 & 22.2 \\
3. Medium & 16.6 & 18.0 \\
4. Dry & 8.6 & 7.0 \\
5. Very Dry & $<6.0$ & $<3.0$ \\
\hline
\end{tabular}

available. Wetland polygons were available from delineations conducted by the United States Forest Service. Once reliable stream reach and water body cells were identified, the relative position of each DEM cell as a distance to the nearest surface water cell (stream or water body); $\Delta \mathrm{X}$ was calculated in a GIS. Our study site has a depth to groundwater map developed from observed well and piezometer data. However, we wanted the WILT method to be applicable to sites without such local groundwater data. As a result, we sought to create a simplified water table surface. To do so, we assume that surface water is outcropped groundwater and used surface water elevations to krige a simplified water table surface. The generated surface was generally flatter than the surface produced from monitoring well data, but was still a reasonable representation of the groundwater surface. We used the simplified groundwater surface to calculate depth-to-groundwater $(\Delta \mathrm{Z})$, by subtracting it from the DEM elevation. The simplified depth-togroundwater $(\Delta \mathrm{Z})$ was then used as an input to calculate WILT.

\subsection{Hydric soils, groundwater, wetlands, and stream reach properties}

Soil characteristics vary across landscapes partly in response to frequency of saturation. Hydric soil units (Fig. 2a) are saturated most of the time, have potentially anaerobic conditions, and are usually found in wetlands and the lower elevations of stream valleys. The United States Forest Service has delineated the hydric soils from NRCS-mapped soil units. In Upper Fourmile, the hydric soil includes highly conductive Pickney, Rembert and Ogeechee sand map units located in the riparian areas and depressions. Wetness indexes were clustered to predict wet and dry regions of our study site. We evaluated the distribution and extent of relative wetness relative to mapped hydric soils of the study site (Fig. 2a).

Observed depth-to-groundwater was used to evaluate the performance of WILT compared to TWI at $10 \mathrm{~m}$ resolution. The observed depth-to-groundwater map was created using the same procedure for the assumed depth-to-groundwater, but with additional observations from 16 wells and 6 piezometers monitored between 2012 and 2013. We combined elevations of outcropped surface water with observed average groundwater levels and kriged them to generate an observed groundwater level map. Depth-to-groundwater was calculated by subtracting the groundwater level from the DEM surface elevation (Fig. 2b). To compare the two indices to groundwater depth, TWI and WILT were classified into wetness categories (Table 1 ) based on percentile rank of the wetness values. Both were classified into five classes, $<10$ th percentile, 10th to 25th, 25th to 75th, 75th to 90th and >90th\% percentile as very dry, dry, medium, wet, and very wet respectively. The spatial distribution of those classes was compared to groundwater depth classes of $<0.5,0.5-2 \mathrm{~m}, 2-3,3-5,5-10,10-15$ and $>15 \mathrm{~m}$ (Fig. 5). LiDAR derived leaf area index observation (Fig. 2c) is proposed as a surrogate for wetness evaluation in the study watershed.

Based on field observations at our site since 2010 we classified the stream reaches into three classes. Perennial reaches that flow yearround, intermittent reaches that flow for part of the year, and ephemeral reaches that flow for a short period after a storm (Fig. 2a). We assessed the distribution of relative wetness values along the sections of stream reaches and evaluated how wetness values change based on stream reach properties along the first order catchment.

\subsection{Soil carbon and nitrogen content}

Soil samples were collected in the hillslope and riparian zone perpendicular to the main intermittent stream of the study watershed on 16 transects (Fig. 1d). There ware a total of 189 sampling units. Each sampling point was georeferenced using an Archer (Juniper Systems Inc.) handheld GPS unit (Hemisphere XF DGPS) so that the sampling points could be matched with the cells of the wetness indices (Drover et al., 2015). Each transects consisted of a varying number of sampling
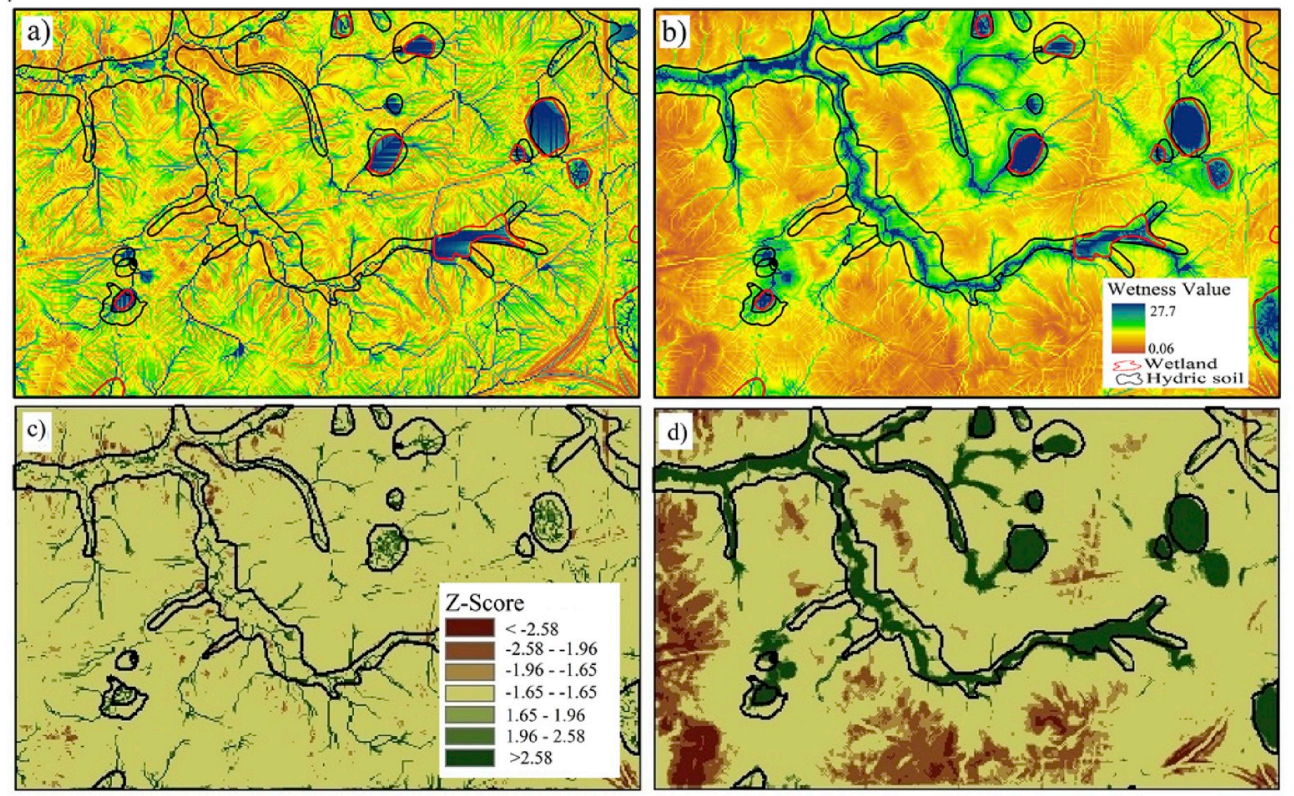

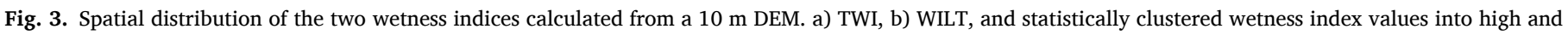

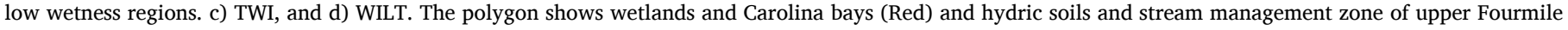
Branch. (For interpretation of the references to colour in this figure legend, the reader is referred to the Web version of this article.) 

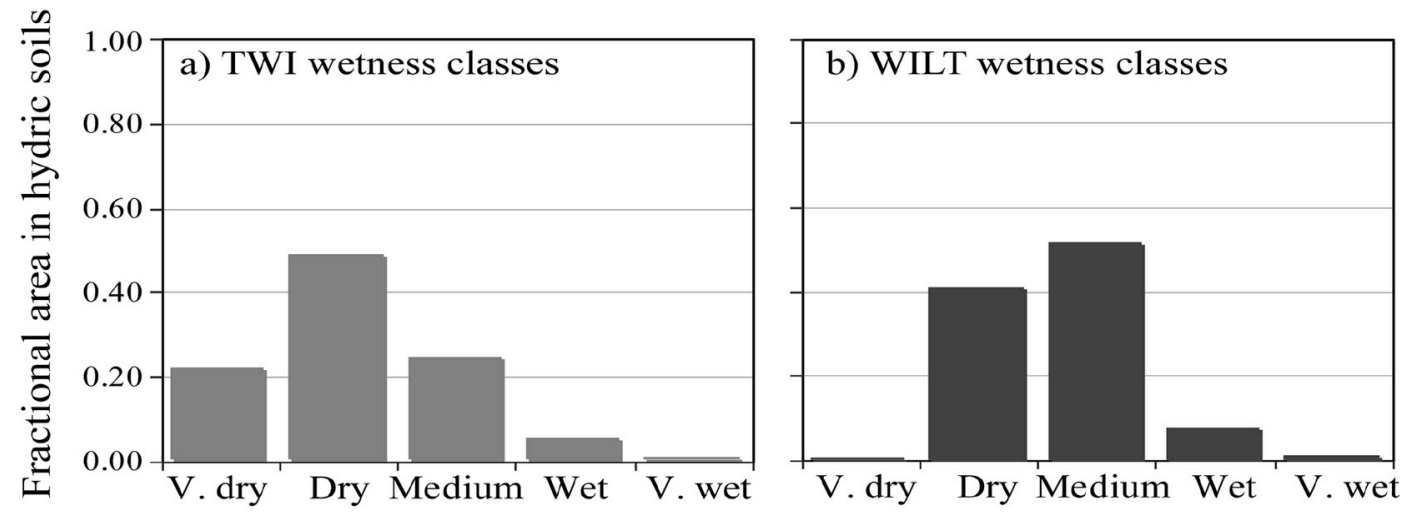

c) TWI

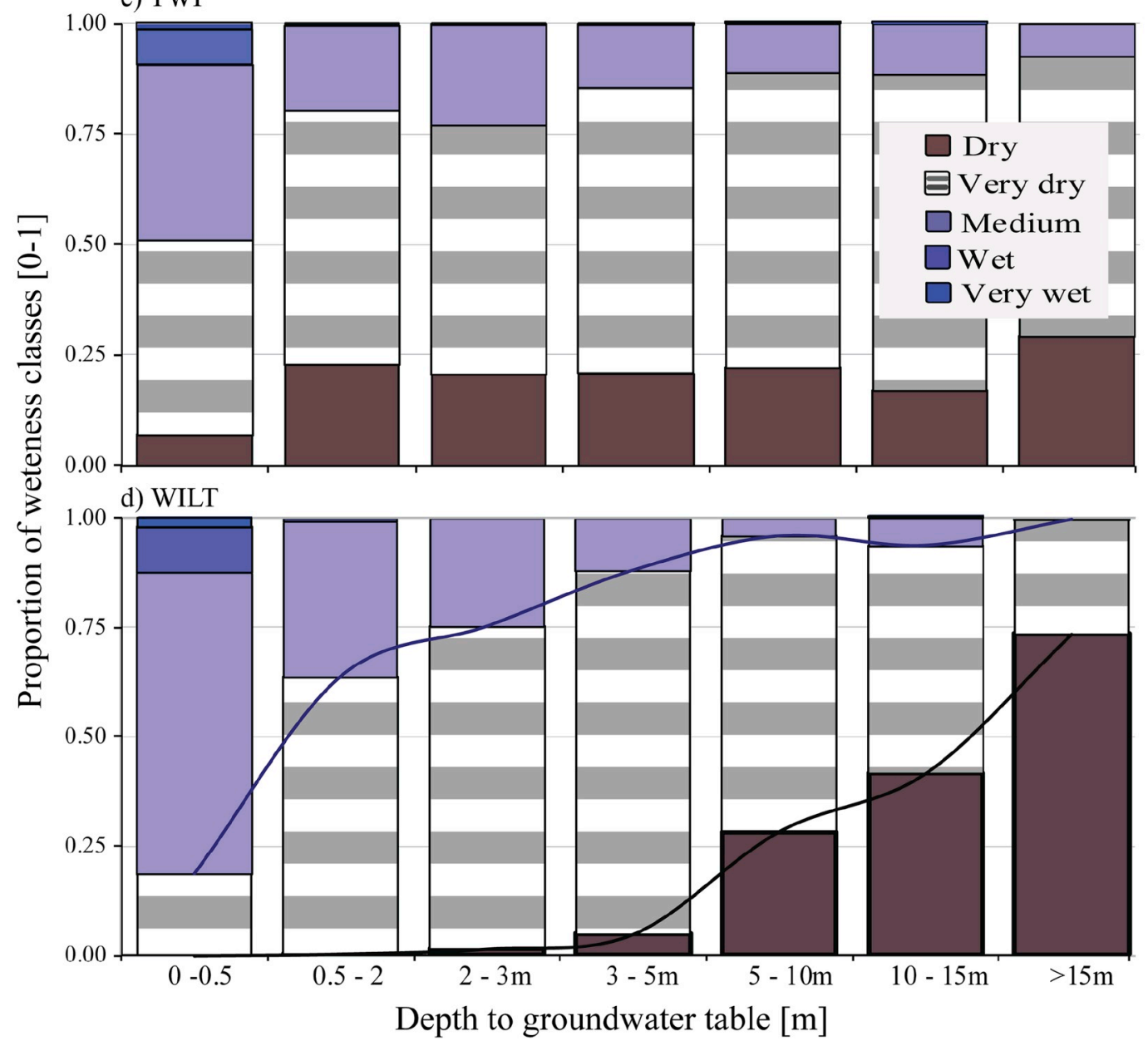

Fig. 4. The distribution of wetness classes in the hydric soil polygons and comparison of the distribution of the wetness classes based on the different ranges of depth to the groundwater table. a) wetness class distribution according to original TWI formula, and b) WILT wetness class distribution, c) distribution of TWI values across ranges of depth to groundwater and d) WILT values.

points and are on average $8 \mathrm{~m}$ apart. The soils were sampled from the A horizon sampling point to a depth of $7.5 \mathrm{~cm}$ using a $201 \mathrm{~b}$. Slide hammer and sleeves with an inner diameter of $7.5 \mathrm{~cm}$. Well-mixed pulverized samples $(1 \mathrm{mg}$ ) were analyzed for $\mathrm{C}$ and $\mathrm{N}$ concentrations using a $\mathrm{CHN}$ elemental analyzer (NC 2100, CE Elantech Inc, Lakewood, NJ) to be used as a surrogate to wetness in order to evaluate the performance of the wetness indices (WILT and TWI). The chemical changes in C and $\mathrm{N}$ molecules in the soil depends on the soil moisture. The evaluation was carried out between the soil characteristics ( $\mathrm{N}$ and $\mathrm{C}$ contents) against the corresponding $10 \mathrm{~m}$ resolution WILT and TWI values to determine the degree of correlation and intuitiveness of the relationships. The comparison was made using the elemental $\mathrm{N}$ and $\mathrm{C}$ concentration from each sample in $\mathrm{kg}$ ha ${ }^{1}$.

\subsection{Spatial cluster analysis of wetness}

To evaluate the ability of TWI and WILT to map wet areas and traditional streamside management zones (SMZs) we performed a spatial cluster analysis. Clustering was analyzed following the Getis and Ord method using the High/Low Clustering tool in ArcGIS (Getis and Ord, 1992). The tool calculates the G statistic which considers the value of each pixel in the context of its neighboring pixels. The values of the G 

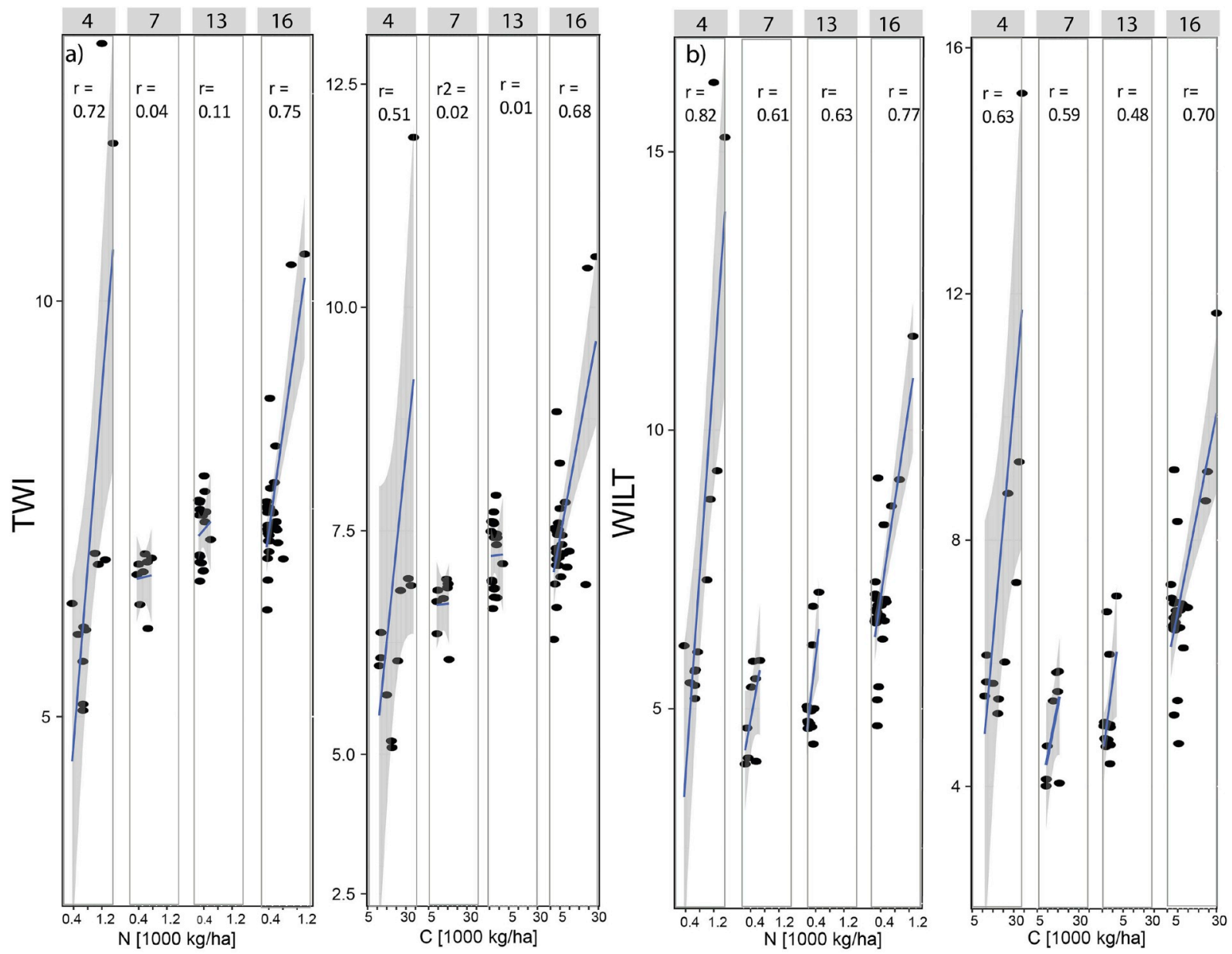

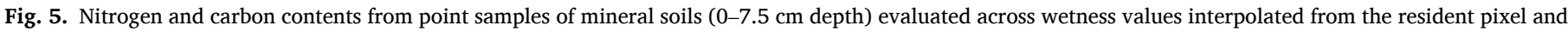
the nearest adjacent pixels, a) TWI, and b) WLIT.

statistic are analyzed in the context of the null hypothesis, which is that there is not spatial clustering of the feature values. The null hypothesis is evaluated based on z-scores and p-values. The higher the z-score, the stronger the intensity of clustering. A z-score near zero indicates no apparent clustering and a negative z-score indicates clustering of low values (Anselin, 1995). With a statistically significant positive $\mathrm{z}$ score, large $\mathrm{z}$ values $(>1.96)$, the null hypothesis is rejected indicating clustering of high values representing wet condition. A statistically significant $\mathrm{z}$ score of less than 1.96 shows clustering of low values representing dry condition.

\subsection{Relative effects of DEM resolution on TWI and WILT maps}

To explore the sensitivity wetness distribution on DEM resolution, we investigated five resolutions for TWI and WILT $(2,5,10,20,30$, and $50 \mathrm{~m}$ ) subsampled from the $1 \mathrm{~m}$ DEM. The evaluations were conducted using the visual inspection of the spatial arrangement of the wetness maps and comparison through basic spatial statistics such as minimum, maximum, interquartile range, mean, and coefficient of variation. We also compared the cumulative distribution plots for each resolution to evaluate the distribution of the effect of DEM resolution on the computed wetness.

\section{Results and discussion}

TWI and WILT produced very different maps of wetness (Fig. 3a and b). The TWI map produces high wetness variability in riparian zones and wetlands, and generates high TWI values dissecting the landscape to the ridgetops (Fig. 3a). WILT created a wetness map more representative of field observations and more consistent with the boundaries of wetlands and hydric soils (Fig. 3b). WILT produced much less variability of wetness indices within wetland and hydric soil polygons, and less variability high on the landscape. WILT significantly reduced the occurrence of high wetness values near ridgetops relative to TWI. Clustering the TWI and WILT maps helps to highlight the differences between the two indices. The clusters of high TWI values delineate the stream channels with high z-scores, but not wet areas adjacent to the channel. In addition, the high TWI clusters delineate dry channels high in the landscape (Fig. 3c). The clusters of high WILT values indicated by high z-scores delineate polygons in the riparian zone that closely correspond to the hydric soil polygons (Fig. 3d). This simple clustering technique highlights WILT's performance in delineating wet areas and provides an example of how wet area maps could be produced with WILT.

TWI and WILT differed substantially in their predictions of hydric soils and wetland polygons (Fig. 3). TWI produces a greater proportion of low values (indicating relatively dry soils) within the hydric soil polygons. According to TWI, relatively dry cells account for about $70 \%$ of the hydric soil polygons while only $30 \%$ of the area was classified as relatively wet (Fig. 4a). Additionally, TWI produces about $22 \%$ very dry cells within the hydric soil polygons. In contrast, WILT produced a negligible proportion (about $0.6 \%$ ) of very dry cells (Fig. $4 \mathrm{~b}$ ) and predicted $60 \%$ relatively wet cells (cells categorized as medium, wet and very wet) within the hydric soil polygons.

The average depth-to-groundwater was negatively correlated to wetness predicted by both models, but the relationship was stronger for 
TWI
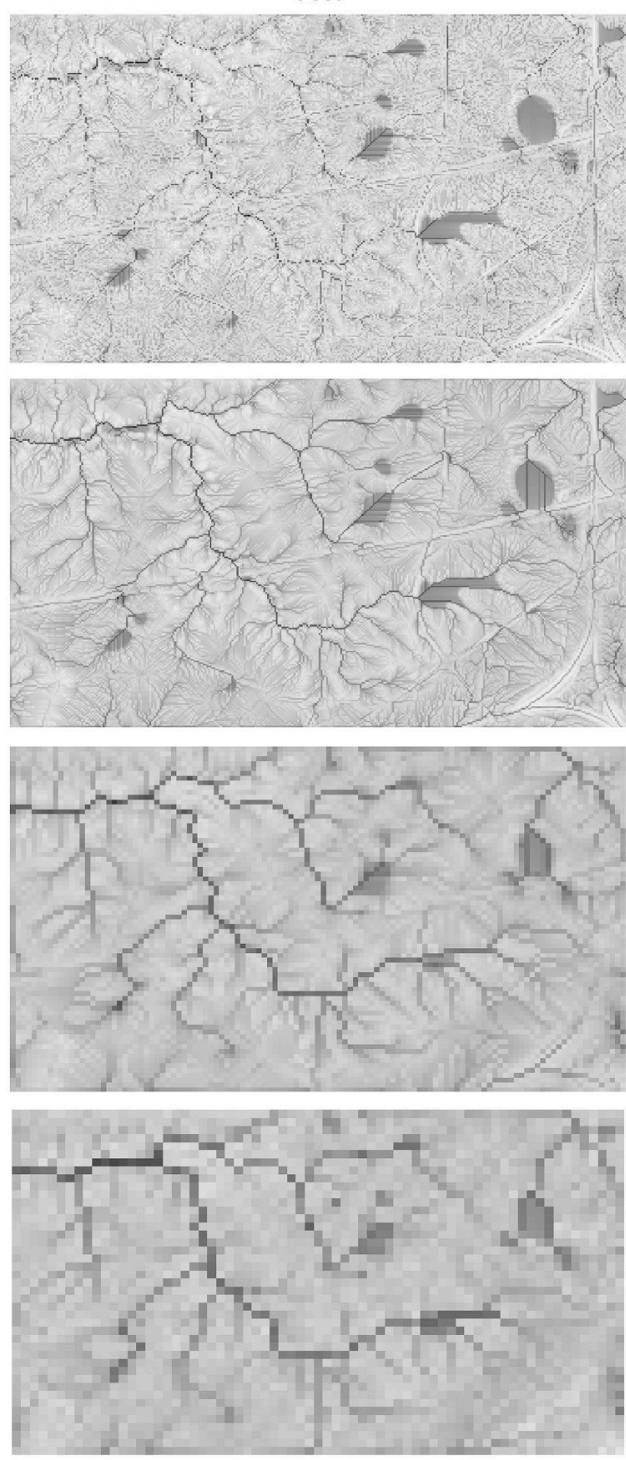

2.62

$$
10.95
$$

$$
24.48
$$

WILT
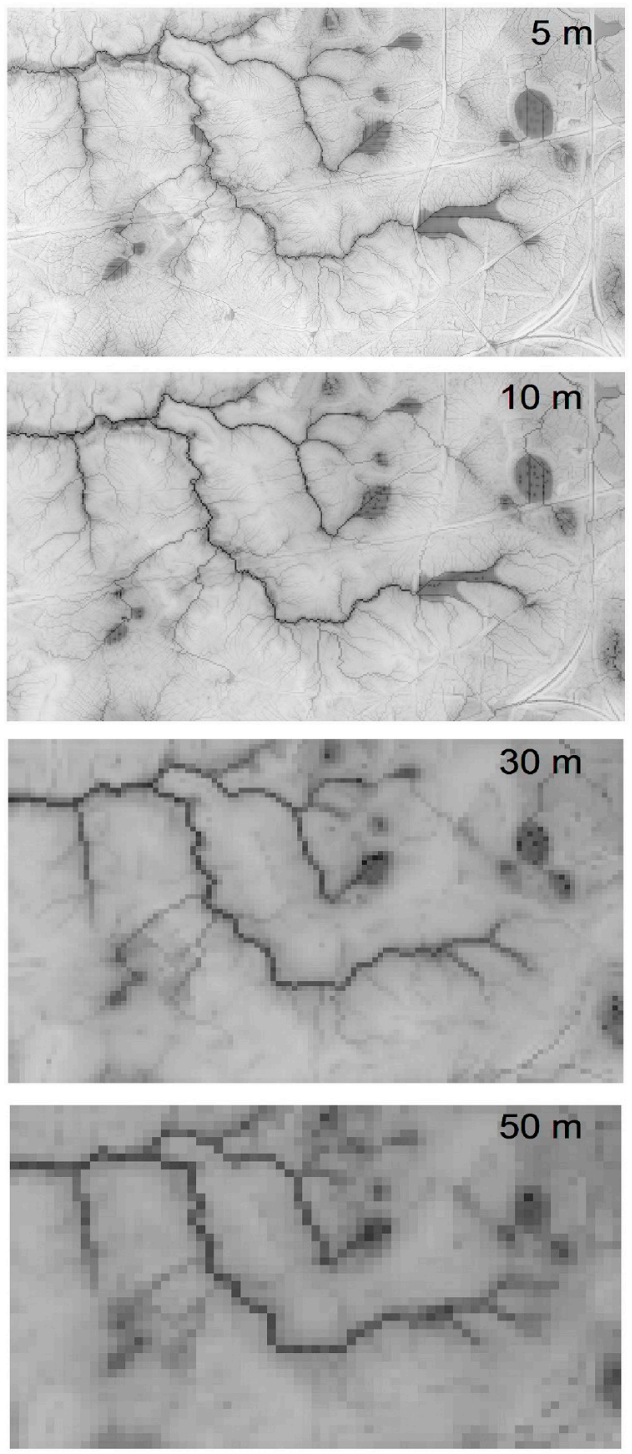

$\begin{array}{lll}-2.38 & 14.00 \quad 25.55\end{array}$

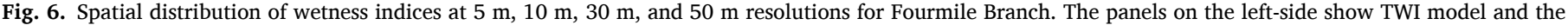

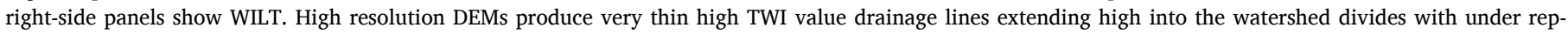

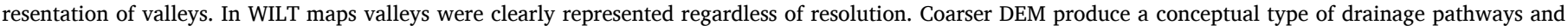
water body.

WILT. Pearson correlation coefficients were 0.53 for WILT and 0.28 for TWI. TWI wetness values appeared relatively insensitive to depth to groundwater, whereas the distribution of WILT values appears strongly influenced by depth to groundwater (Fig. 4c and d). With WILT, the proportion of dry cell area increased with increasing depth to groundwater and the proportion of wet cells decreased as the depth-togroundwater increased (see the guide line on Fig. 4d).

It is also important to note the similarities between the TWI and WILT as both are based on the same assumptions regarding the control of the distribution of moisture across the landscapes. The comparison between the wetness values alsong the stream channels showed equal relative spatial variability (see Supplimentary Material Text S1 and Fig. S1) indicating the similarity between the two indices for locations of similar landscape position.

Evaluation of soil C and N contents against WILT and TWI values interpolated from the resident and nearest pixels indicated that WILT wetness estimation significantly improved the correlation with both $\mathrm{N}$ and $\mathrm{C}$ concentrations in the soil samples (Fig. 5). The correlation coefficient $(\mathrm{r})$ of the entire sample data increased from $0.38(\mathrm{~N})$ and $0.25(\mathrm{C})$ for TWI to $0.66(\mathrm{~N})$ and $0.52(\mathrm{C})$ for WILT (see Supplimentary Material Fig. S2). In most cases, correlations between the $10 \mathrm{~m}$ resolutions of TWI and soil carbon and nitrogen contents were weak, with an average correlation values across of the 16 transects equal to 0.31 which is close to the literature values of 0.4 (e.g. Florinsky et al., 2002; Sorenson et al., 2006; Sorensen and Seibert, 2007). With WILT methodology, the correlation values improved substantially to an average correlation of 0.6 , indicating that WILT incorporated subsurface controls better for landscape wetness representation. Welsch et al. (2001) found that TWIs explained $56 \%$ of the variation in subsurface nitrate concentrations, by far the best-reported performance for TWI prediction of landscape and soil attributes. The improvement in wetness index estimation using landscape positions was definite with a significant bump in the 
Table 2

Statistical comparison of distribution of WILT and TWI values in Upper Fourmile at 2 m, 5 m, 10 m, 20 m, 30 m, and 50 m DEM resolutions.

\begin{tabular}{|c|c|c|c|c|c|c|c|c|c|c|c|c|}
\hline \multirow[t]{2}{*}{ Wetness Statistics } & \multicolumn{6}{|l|}{ TWI } & \multicolumn{6}{|l|}{ WILT } \\
\hline & $2 \mathrm{~m}$ & $5 \mathrm{~m}$ & $10 \mathrm{~m}$ & $20 \mathrm{~m}$ & $30 \mathrm{~m}$ & $50 \mathrm{~m}$ & $2 \mathrm{~m}$ & $5 \mathrm{~m}$ & $10 \mathrm{~m}$ & $20 \mathrm{~m}$ & $30 \mathrm{~m}$ & $50 \mathrm{~m}$ \\
\hline Minimum & 0.8 & 2.6 & 3.5 & 4.7 & 5.4 & 5.1 & 5.7 & 2.4 & 0.1 & 2.4 & 3.8 & 5.5 \\
\hline Maximum & 24.9 & 24.5 & 23.8 & 19.9 & 20.3 & 19.1 & 29.3 & 25.4 & 27.8 & 25.6 & 23.4 & 21.6 \\
\hline Mean & 5.7 & 6.8 & 7.5 & 8 & 8.4 & 8.6 & 0.7 & 3.1 & 4.8 & 6.9 & 8.1 & 9.8 \\
\hline Standard deviation & 2.4 & 2.1 & 2 & 1.9 & 1.8 & 1.9 & 3.4 & 3.1 & 2.8 & 2.9 & 2.7 & 2.7 \\
\hline Coefficient of Variation & 0.4 & 0.3 & 0.3 & 0.2 & 0.2 & 0.2 & 5.2 & 1 & 0.6 & 0.4 & 0.3 & 0.3 \\
\hline
\end{tabular}

correlation values (see Supplimentary Material Fig. S2).

The analysis of effects of DEM resolution indicated that spatial distributions of wetness values were sensitive to DEM resolution in both models, but the spatial distribution of TWI values was more sensitive than WILT values (Fig. 6). DEM scale affects the distribution of both indices with more smoothing and shifting of the wetness values higher as resolution decreased. The WILT map has less variability in spatial predictions across the DEM resolutions and more consistently delineates wet areas than TWI (Fig. 6). The WILT maps appear fundamentally similar from 5 to $50 \mathrm{~m}$ resolutions, whereas the $5 \mathrm{~m}$ TWI map appears fundamentally different from the $50 \mathrm{~m}$ TWI map. TWI maps showed large variability of wetness values in cells adjacent to the drainage pathways. In finer resolution maps, the drainage pathways are narrower, more numerous and extend to ridgetops. As DEM scale increases, the size of stream pathways become larger showing better resemblance to the observed stream valleys in the study area at $20-30 \mathrm{~m}$ resolutions. Previous studies have shown that DEM resolution affects the distribution and spatial patterns of TWI (e.g. Quinn et al., 1991; Zhang and Montgomery, 1994; and Wolock and Price, 1994) and on the implications of hydrologic responses of TOPMODEL simulation framework (e.g. Wolock and Price, 1994).

Cumulative distribution functions of TWI and WILT both show shifts toward higher values as DEM resolution decreased (Table 2 and Supplimentary Material Fig. S3). The mean WILT value increased significantly from 0.66 for a $2 \mathrm{~m}$ resolution to 9.8 for $50 \mathrm{~m}$ while TWI values increased from 5.7 for $2 \mathrm{~m}$ to 8.6 for $50 \mathrm{~m}$ resolution. There is a difference in how the distributions shifted between the two indices.

\section{Conclusions}

Our observations of the distribution of soil characteristics in the porous, low-slope, groundwater dominated watersheds of the southeastern Coastal Plain suggested that an alternative to TWI was needed to predict landscape characteristics affected by soil wetness. In landscapes where interflow occurs, but percolation and groundwater flow are the dominant hydrologic processes, the hydrologic assumptions of TWI are violated, and thus the TWI has difficulty predicting the spatial distribution of relative wetness. Specifically, TWI predicts too many dry pixels in low elevation valleys and wetlands and too many wet pixels on ridges. Based on the observation that in low-slope, groundwater dominated landscapes, soils are generally wetter near nearer the streams and lower in the landscape, we created the Wetness Index modified by Landscape Position and Topography, WILT, by inversely weighting TWI by the product of the distance to the nearest stream and a simple estimate of the depth to the water table. We created WILT so that it would need only topographic and hydrographic information, so the depth to the water table is created by a simple fitting of a water table to known surface water elevations. We then compared TWI and WILT maps of relative wetness with respect to hydric soil and wetland polygons, depth-togroundwater determined from both well data and surface water positions, soil carbon and nitrogen content, and sensitivity to DEM scale.

WILT maps of relative wetness performed better than TWI based on comparison to mapped hydric soils, wetlands, and observed groundwater depths generated from a network of monitoring wells. WILT produced less small scale wetness variability produced by small scale variations in surface topography. For example, WILT reduced the proportion of dry cells in shallow groundwater locations and the proportion of the wet cells in on ridges where the water table is deep. WILT predicted about $60 \%$ cells within the hydric soil polygon as wet cells and less than $1 \%$ of very low wetness values which are consistent with visual assessments of valley bottom wetness, in contrast, TWI produced $29 \%$ wet and $22 \%$ very low wet cells. WILT produced much higher correlations with soil $\mathrm{C}$ and $\mathrm{N}$ contents measured in multiple transects. Comparison across four different DEM resolutions showed that both WILT and TWI indices were sensitive to DEM resolution. However, the spatial structure of WILT values showed strong similarity across the resolutions, whereas the spatial structure of TWI values differed greatly across resolutions. Application of WILT in the leaky, groundwater-dominated environment showed better accuracy for wetness prediction across landscapes, which can be used in land and water resource management and conservation planning and environmental quality improvement projects.

\section{Author contributions}

Menberu B. Meles: Conceptualization, methodology, software, writing - original draft preparation, visualization, investigation, and validation. Seth E. Younger: Conceptualization, software, visualization, and investigation. C. Rhett Jackson: Supervision, conceptualization writing and editing. Enhao Du: writing and editing. Damion Drover: writing and editing

\section{Acknowledgement}

This research was implemented as part of large-scale collaborative investigation of dominant hydrologic processes within small watersheds of the Sandhills of South Carolina within the Savannah River Site (SRS). SRS is a National Environmental Research Park. Support was provided by the Department of Energy-Bioenergy Technologies Office and Savannah River Operations Office through the U.S. Forest Service Savannah River under Interagency Agreement DE-AI09-00SR22188.

\section{Appendix A. Supplementary data}

Supplementary data to this article can be found online at https://doi. org/10.1016/j.jenvman.2019.109863.

\section{References}

Aadland, R.K., Gellici, J.A., Thayer, P.A., 1995. Hydrogeologic Framework of WestCentral South Carolina, Report 5, Water Resource Division, South Carolina Department of Natural Resources (Columbia, SC).

Ali, G., Birkel, C., Tetzlaff, D., Soulsby, C., McDonnell, J.J., Tarolli, P., 2013. A comparison of wetness indices for the prediction of observed connected saturated areas under contrasting conditions. Earth Surf. Process. Landforms 39, 399-413. https://doi.org/10.1002/esp.3506.

Anselin, L., 1995. Local indicators of spatial association - LISA. Geogr.1 Anal. 27, 93-115. Beven, K.J., 1986. Runoff production and flood frequency in catchments of order n: an alternative approach. In: Gupta, V.K., Rodriguez-Iturbe, I., Wood, E.F. (Eds.), Scale Problems in Hydrology. Reidel, Dordrecht, pp. 107-131.

Beven, K.J., Kirkby, N.J., 1979. A physically based variable contributing area model of basin hydrology. Hydrol. Sci. Bull. 24, 43-69.

Case, B.S., Meng, F.-R., Arp, P.A., 2005. Digital elevation modelling of soil type and drainage within small forested catchments. Can. J. Soil Sci. 85, 127-137. 
Dosskey, M.G., Qiu, Z., 2011. Comparison of indexes for prioritizing placement of water quality buffers in agricultural watersheds. J. Am. Water Resour. Assoc. 47 (4), 662-671. https://doi.org/10.1111/j.1752-1688.2011.00532.x.

Dosskey, M.G., Qiu, Z., Kang, Y., 2013. A comparison of DEM-based indexes for targeting the placement of vegetative buffers in agricultural watersheds. J. Am. Water Resour. Assoc. 49 (6), 1270-1283. https://doi.org/10.1111/jawr.12083.

Drover, D., Jackson, R.C., Bitew, M., E Du, E., 2015. Effects of DEM scale on the correlation of topographic wetness indices to watershed and soil characteristics. Hydrol. Earth Syst. Sci. Discuss. 11817-11836.

Du, E., Jackson, R.C., Klaus, J., McDonnell, J.J., Griffiths, N.A., Williamson, M.F., Greco, J.L., Bitew, M., 2016. Interflow dynamics on a low relief forested hillslope: lots of fill, little spill. J. Hydrol. 534, 648-658. https://doi.org/10.1016/j. jhydrol.2016.01.039, 0022-1694.

Epting, S.M., Hosen, J.D., Alexander, L.C., Lang, M.W., Armstrong, A.W., Palmer, M.A., 2018. Landscape metrics as predictors of hydrologic connectivity between Coastal Plain forested wetlands and streams. Hydrol. Processes 32, 516-532. https://doi.or g/10.1002/hyp.11433.

Florinsky, I.V., Eilers, R.G., Manning, G.R., Fuller, L.G., 2002. Prediction of soil properties by digital terrain modelling. Environ. Model. Softw 17, 295-311.

Getis, A., Ord, J.K., 1992. The analysis of spatial association by use of distance statistics. Geogr.1 Anal. 24, 189-206, 1992.

Griffiths, N.A., Jackson, C.R., McDonnell, J.J., Klaus, J., Du, E., Bitew, M., 2016. Dual nitrate isotopes clarify the role of biological processing and hydrologic flowpaths on nitrogen cycling in subtropical low-gradient watersheds. J. Geophys. Res. Biogeosciences 121 (2), 422-437.

Griffiths, N.A., Jackson, C.R., Bitew, M.M., Fortner, A.M., Fouts, K.L., McCracken, K., Phillips, J.R., 2017. Water quality effects of short-rotation pine management for bioenergy feedstocks in the southeastern United States. For. Ecol. Manag. 400, 181-198.

Güntner, A., Seibert, J., Uhlenbrook, S., 2004. Modeling spatial patterns of saturated areas: an evaluation of different terrain indices. Water Resour. Res. 40, 1-19.

Higginbottom T. P., C.D. Field, A.E. Rosenburgh, A. Wright, E. Symeonakis, S.J.M. Caporn, High-resolution wetness index mapping: A useful tool for regional scale wetland management, Ecol. Inf., 48, 89-96, https://doi.org/10.1016/j.ecoinf.2018.0 8.003 .

Iverson, L.R., Prasad, A.M., Rebbeck, J., 2004. A comparison of the integrated moisture index and the topographic wetness index as related to two years of soil moisture monitoring in Zaleski State Forest, Ohio. In: Yaussy, D.A., Hix, D.M., Long, R.P., Goebel, P.C. (Eds.), 14th Central Hardwoods Forest Conference. U.S. Department of Agriculture, Forest Service, Wooster, OH, pp. 515-517.

Jackson, C.R., Bitew, M., Du, E., 2014. When interflow also percolates: downslope travel distances and hillslope process zones. Hydrol. Process. 28, 3195-3200. https://doi. org/10.1002/hyp.10158.

Jackson, C.R., Du, E., Klaus, J., Griffiths, N.A., Bitew, M., McDonnel, J.J., 2016. Interactions among hydraulic conductivity distributions, subsurface topography, and transport thresholds revealed by a multitracer hillslope irrigation experiment. Water Resour. Res. 52, 6186-6206. https://doi.org/10.1002/2015WR018364.

Jancewicz, K., Migon, P., Kasprzak, M., 2019. Connectivity patterns in contrasting types of tableland sandstone relief revealed by Topographic Wetness Index. Sci. Total Environ. 656, 1046-1062. https://doi.org/10.1016/j.scitotenv.2018.11.467, 00489697.

Kienzle, S., 2004. The effect of DEM raster resolution on first order, second order and compound terrain derivatives. Trans. GIS 8 (1), 83-111.

Kilgo, J.C., Blake, J.I., 2005. Ecology and Management of a Forested Landscape. Island Press.

Kirkby, M.J., 1975. Hydrograph modelling strategies. In: Peel, R., Chisholm, M., Haggett, P. (Eds.), Process in Physical and Human Geography. Heinemann, London, pp. 69-90.

Kirkby, M.J., Weyman, D.R., 1974. Measurements of Contributing Area in Very Small Drainage Basins. Seminar Series B, No. 3. Department of Geography, University of Bristol, Bristol.

Kirkby, M.J., 1978. Implications for sediment transport. In: Kirkby, M.J. (Ed.), Hillslope Hydrology. Wiley, London, pp. 325-363.

Klaus, J., McDonnell, J.J., Jackson, C.R., Du, E., Griffiths, N.A., 2015. Where does streamwater come from in low relief forested watersheds? A dual isotope approach. Hydrol. Earth Syst. Sci. 19, 125-135.
Lang, M.W., McCarty, G.W., Oesterling, R., Yeo, I., 2013. Wetlands. Topographic Metrics for Improved Mapping of Forested Wetlands, 33, pp. 141-155. https://doi.org/ 10.1007/s13157-012-0359-8.

Li, X., McCarty, G., Karlen, D., Cambardella, C., 2018a. Topographic metric predictions of soil redistribution and organic carbon in Iowa cropland fields. Catena 160, $222-232$.

Li, X., McCarty, G., Lang, M., Ducey, T., Hunt, P., Miller, J., 2018b. Topographic and physicochemical controls on soil denitrification in prior converted croplands located on the Delmarva Peninsula, USA. Geoderma 309, 41-49.

Ma, J., Lin, G., Chen, J., Yang, L., 2010. An improved topographic wetness index considering topographic position. In: Proceeding of the 18th International Conference on Geoinformatics: GIScience in Change, Geoinformatics. Peking University, Beijing, pp. 18-20. June 201.

Maidment, D.R. (Ed.), 2002. Arc Hydro: GIS for Water Resources. ESRI Press, Redlands, Ca.

Marthews, T.R., Dadson, S.J., Lehner, B., Abele, S., Gedney, N., 2014. A high-resolution global dataset of topographic index values for use in large-scale hydrological modelling. Hydrol. Earth Syst. Sci. Discuss. 11, 6139-6166.

Mohamedou, C., Korhonen, L., Eerikainen, K., Tokola, T., 2019. Using LiDAR-modified topographic wetness index, terrain attributes with leaf area index to improve a single-tree growth model in south-eastern Finland. Forestry: Int. J. Financ. Res. 92 (3), 253-263. https://doi.org/10.1093/forestry/cpz010.

Moore, D., Gessler, P.E., Nielsen, G.A., Peterson, G.A., 1993. Soil attribute prediction using terrain analysis. Soil Sci. Soc. Am. J. 57, 443-452.

Murphy, P.N.C., Ogilvie, J., Meng, F.-R., White, B., Bhatti, J.S., Arp, P.A., 2011. Modelling and mapping topographic variations in forest soils at high resolution: a case study. Ecol.1 Model. 222, 2314-2332.

Murphy, P.N.C., Ogilvie, J., Arp, P., 2009. Topographic modelling of soil moisture conditions: a comparison and verification of two models. Eur. J. Soil Sci. 60, 94-109.

Quinn, P., Beven, K., Chevallier, P., Planchon, O., 1991. The prediction of hillslope flow paths for distributed hydrological modelling using digital terrain models. Hydrol. Process. 5 (1), 59-79.

Robson, A., Beven, K., Neal, C., 1992. Towards identifying sources of subsurface flow: a comparison of components identified by a physically based runoff model and those determined by chemical mixing techniques. Hydrol. Process. 6, 199-214.

Sorensen, R., Seibert, J., 2007. Effects of DEM resolution on the calculation of topographical indices: TWI and its components. J. Hydrol. 347, 79-89.

Sørensen, R., Zinko, U., Seibert, J., 2006. On the calculation of the topographic wetness index: evaluation of different methods based on field observations. Hydrol. Earth Syst. Sci. 10, 101-112. https://doi.org/10.5194/hess-10-101-2006.

Wallace, C.W., McCarty, G., Lee, S., Brooks, R.P., Veith, T.L., Kleinman, P.J.A., Sadeghi, A.M., 2018. Evaluating concentrated flowpaths in riparian forest buffer contributing areas using LiDAR imagery and topographic metrics. Remote Sens. 10, 614. https://doi.org/10.3390/rs10040614.

Walter, M.T., Steenhuis, T.S., Mehta, V.K., Thongs, D., Zion, M., Schneiderman, E., 2002. A refined conceptualization of TOPMODEL for shallow-subsurface flows. Hydrol. Process. 16, 2041-2046.

Welsch, D.L., Kroll, C.N., McDonnell, J.J., Burns, D.A., 2001. Topographic controls on the chemistry of subsurface stormflow. Hydrol. Processes 15 (10), 1925-1938.

Western, A.W., Grayson, R.B., Bloschl, G., Willgoose, G.R., McMahon, T.A., 1999. Observed spatial organization of soil moisture and its relation to terrain indices. Water Resour. Res. 35 (3), 797-810.

Wolock, D.M., Price, C.V., 1994. Effec.ts of digital elevation model map scale and data resolution on a topography-based watershed model. Water Resour. Res. 30 (11), 3041-3052.

Woods, R.A., Sivapalan, M., 1997. A connection between topographically driven runoff generation and channel network structure. Water Resour. Res. 33, 2939-2950.

Woods, R.A., Sivapalan, M., Duncan, M.J., 1995. Investigating the representative elementary area concept: an approach based on field data. Hydrol. Process. 9, 291-312.

Zhang, W., Montgomery, D.R., 1994. Digital elevation model grid size, landscape representation, and hydrologic simulations. Water Resour. Res. 30, 1019-1028.

Zinko, U., 2004. Plants Go with the Flow - Predicting Spatial Distribution of Plant Species in the Boreal Forest. PhD thesis. Umea University, Department of Ecology and Environmental Science, ISBN 91-7305-705-3.

Zinko, U., Seibert, J., Dynesius, M., Nilsson, C., 2005. Plant species numbers predicted by a topography based groundwater-flow index. Ecosystems 8, 430-441. 